\title{
Customer satisfaction and customer loyalty through service quality evaluated under SERVQUAL model- a study on banking industries of Bangladesh
}

\author{
Md. Ariful Islam ${ }^{1}$, Kh. Fahim Hossain ${ }^{2}$, Md. Rayhan Islam ${ }^{3}$, Mahmudul Hasan Siddiqui ${ }^{4}$ \\ ${ }^{1}$ BASIC Bank Limited, Khulna, Bangladesh \\ ${ }^{2}$ Chevron Bangladesh, Dhaka, Bangladesh \\ ${ }^{3}$ Business Administration Discipline, Khulna University, Khulna-9208, Bangladesh \\ ${ }^{4}$ Unilever Bangladesh Limited, Gulshan-1, Dhaka-1212, Bangladesh
}

\author{
Email address: \\ arifrussell@yahoo.com (M. A. Islam),khfahim04@yahoo.com (Kh. F. Hossain), rayhan_07@yahoo.com (Md. R. Islam) \\ mhs.sadi@gmail.com (M. H. Siddiqui)
}

\section{To cite this article:}

Md. Ariful Islam, Kh. Fahim Hossain, Md. Rayhan Islam, Mahmudul Hasan Siddiqui. Customer Satisfaction and Customer Loyalty through Service Quality Evaluated under SERVQUAL Model- A study on Banking Industries of Bangladesh. Science Journal of Business and Management. Vol. 1, No. 4, 2013, pp. 88-97. doi: 10.11648/j.sjbm.20130104.15

\begin{abstract}
Contemporary business world is very much competitive and the success in the competition is achieved mainly through giving satisfaction to the ultimate consumer. In service oriented industry, it is very difficult to set a standard rule to satisfy customers. Several factors influence customer's decision making to take the service from an organization. The banking industry is a service industry; it provides the customer various financial services. So a banking organization must be keen in identifying the factors which influence their decision in taking the financial service. Thus the bank also needs to know the perception and satisfaction level of the customers about their performance. From the study it is found that significant portion of customers is businessman and private service holder. The customers' satisfaction level towards the overall performance level is quite better. The most positive response factors are products (Average mean value 4.41), procedures of services (average mean score 3.99, charges (average mean score 4.00) and performance of the employee (average mean value 4.11). They are neutral in rate of interest (average mean score 3.67) and physical environment and support (average mean value 3.60). In the last part analysis of the variation in opinion due to demographic difference, it is found that the businessmen are more satisfied by the overall services of BASIC Bank Ltd, Khulna Branch than the service holders. And the customer whose income is between TK. 10000-40000 is more satisfied than the other two groups on average. Moreover, customers whose income is between TK.40000-80000 is less satisfied on average of the six factors. So BASIC Bank Ltd, Khulna Branch need to be concern to remove their dissatisfaction through adopting new mechanism and it will help the bank win customers and increase their profitability.
\end{abstract}

Keywords: Satisfaction, Customer, Banking, Environment, Attitude, Loyalty, Servqual, Service Quality

\section{Introduction}

\subsection{Background of the Study}

Services are increasingly becoming a larger portion of any organizations', like bank's regional, national, and global operation and are being considered as an indispensible tool for revenue streams (Angur, et al., 1999 cited in Dhandabani, 2010). Rapid rise of alternative financial service institutions with some other regulatory, structural and technological factors have significantly changed the environment of banking industry throughout the world and led it into the red ocean of competition It is well known fact that success of a service provider depends on the long term relationship with customers which is determined by customer satisfaction and loyalty (Mosahab, et al., 2010). It is also well established by worldwide researches that higher service quality results in customer's satisfaction and loyalty, greater willingness to recommend to someone else, reduction in complaints and improved 
customer retention rates (Danaker, 1997; Magi and Julander, 1996; Levesque and McDongall, 1996 cited in Dhandabani, 2010) increase in sales profit and market share, enhancement of enhance corporate image and thereby organizational outcome toward superior performance and sustainable competitive advances (Mosahab, et al., 2010). However as services possess some unique characteristics other than goods; measurement of service quality is very difficult. The objective of this study is to measure impact of service quality on customer satisfaction and loyalty from the perspective of banking industry of Bangladesh (Thakur, 2011).

\subsection{Objective of the Study}

Primary objective of this study is to find out the interrelationship among service quality, customer satisfaction and customer loyalty in banking industry of Bangladesh.

To support this objective, the study has focused on some secondary objectives like:

To reveal the dimensions of service quality in commercial banks.

- To explore the condition of service quality in Bangladeshi commercial banks.

- To find out the reasons that led to customer satisfaction.

- To analyze the factors influencing the customer loyalty in the banking industry of Bangladesh.

- To examine the influence of perceived quality on satisfaction.

- To investigate the influence perceived quality and satisfaction on loyalty.

\subsection{Background: Banking Industry in Bangladesh}

The banking industry in Bangladesh has grew over the years, making double-digit profit percentages, sustaining growth and surviving cut-throat competition while providing attractive returns to shareholders. Bangladesh is a bank-dominated economy where banking sector relative to the size of its economy is comparatively larger than many economies of similar level of development and per capita income. The non-bank financial sector, including capital market institutions is only a small percentage of GDP, which is much smaller than the banking sector (Rashid, 2010). Name of central bank of Bangladesh is Bangladesh Bank. This country has got four state owned commercial banks (Sonali, Agrani, Rupali and Janata), about 34 private commercial banks (like- AB, Al-Arafah Islami Bank, Bank Asia Limited, BRAC, City Bank Limited, DBBL, Eastern, Exim, ICB, IFIC, Islamic Bank, Mercantile, Prime, Pubali, Social Islami Bank, Trust Bank Limited etc.), about 22 foreign commercial banks (like American Express Bank Citibank N.A., HSBC, ICICI, National Bank of Pakistan, Standard Chartered Bank, State Bank of India etc.) and about 12 specialized development banks (like Ansar VDP Unnyan Bank, Development Bank Ltd, Krishi Bank,
Somobay Bank Limited, Shilpa Bank, Shilpa Rin Sangstha, BASIC, Grameen Bank, Karmasangsthan Bank etc.). Banking sector alone accounts for about 95 percent of assets of the financial system in Bangladesh. Total number of scheduled bank branches has gradually risen to from 5042 at the end of December 1985 to 6936 in June 2009. The structure of the banking system has changed substantially over the last few years. The market share of the Government owned banks declined substantially while Private Commercial Banks' share rose and the foreign commercial banks showed a slight increase. The banking system is dominated by the 4 state owned banks, which in operated by 3387 branches (49.0 percent of the total) and together controlled 29.50 percent of deposits of in June 30, 2009. Despite their dominance and reasonably robust growth, these banks have been losing market share due to the rapid growth of private banks for their better service to the customers. The domestic private bank's growth is even more impressive. On the other hand, foreign banks' market share has remained more or less unchanged (aimsbangladesh.com, 2002; Bahar, 2009 \& Rashid, 2010).

\subsection{Methodology of the Study}

Interrelationship among service quality, customer satisfaction and customer loyalty has been analyzed following some steps which are shown in this diagram:

Reliability, empathy, responsiveness, tangibles, recovery, knowledge and perceived value are the dimensions that have been used to analyze the level of service quality which in turn is supposed to be the ultimate determinant of customer satisfaction. Then customer satisfaction has been perceived to be transformed into customer loyalty.

\subsection{Data Collection}

The main objective of this study is to find out the interrelationship among service quality, customer satisfaction and customer loyalty in banking industry of Bangladesh and the study is based on Khulna city. For conducting any study, the collection of data or information, processing \& making the best use of it is the key factor. Therefore a descriptive research methodology has been conducted for this study. The population of the research is entire people of Bangladesh but data have been collected from a sample of 20 customers who have bank account in different private banks in Khulna. The respondents include- student, employee and business personnel. The average age of the respondents was 24-32 years. $65 \%$ respondents were male and $35 \%$ were female.

A structured closed-ended questionnaire with 49 questions under 9 variables have been developed based on SERVQUAL model. Responses of the questions have been examined by collecting data through face to face interview of a heterogeneous population on five point Likert scale, where targeted respondents come from the general open public (from difference genders, races, age groups, marital status, education backgrounds, designations and 
professionalisms) and then the data have been measured by fitted statistical tools. A sample of the questionnaire has been given in Appendix (Page No. 23).

\subsection{Data Analysis}

Descriptive statistics (Mean and standard deviation) and the Correlations of coefficients of the studied variables have been computed and presented in Table form. The correlations of coefficient for the different variables have been computed using SPSS (version 16.0) and Microsoft Excel has been used to find means and standard deviations of the variables.

The Pearsonian co-efficient of correlation is most widely used for summarizing the degree and direction of relationship between two variables and the value always lies between \pm 1 (Gupta and Gupta, 2005). Gupta and Gupta (2005) and Morgan et al. (2004) cited in Siddiqi (2011) stated that:

- 1.0 (a perfect negative correlation)

- (no correlation)

- $\quad+1.0$ (a perfect positive correlation)

This study is based on this mechanism. The correlation procedure has been subject to two tailed tests of statistical significance at two different levels- highly significant $(\mathrm{p}<0.01)$ and significant $(\mathrm{p}<0.05)$.

\section{Literature Review}

\subsection{Service Quality}

The present business era is now named as "Quality Era" because perceived quality of the product is becoming the most important competition factor in business world (Peeler, 1996 cited in Mosahab, et al., 2010). It is now the most powerful competition weapon and organization's lifegiving blood. Perceived service quality refers to the consumer's global attitude or judgment of the overall excellence or superiority of the service. It is a multiattribute constructs results from comparisons by consumers of expectations with their perceptions of service that dictates the overall evaluation of a firm (Lehtinen \& Lehtinen, 1982; Takeuchi and Onelch, 1983; Lewis \& Booms, 1983; Gronroos, 1984; Parasuraman et al., 1985; 1988; Zeithaml, 1988; Lewis et al., 1994; Caruana, 2002 cited in Kheng, 2010). That means it can be termed as the extent of matching or the degree of discrepancy to which the service delivered matches customer expectations (Lewis and Booms, 1983 \& Parasuraman et al., 1985 cited in Kheng, 2010). Delivering quality service means conforming to customer expectations on a consistent basis (Thakur, 2011).

Today one of the most dominant topics of research in services is service quality (Fist et al., 1993 cited in Thakur, 2011) as it is necessary for service providers to understand how customers evaluate the quality of service offerings, choose organization and the basis on which they build longterm patronage. When customers consume a product, they compare the quality of experience with their prior expectations (Swan and Comb, 1976 cited in Thakur, 2011), which leads to their satisfaction or dissatisfaction. Therefore services marketing researchers based their work on developing a service quality concept focused on consumer behavior instead of using manufacturing quality concepts (Brown et al., 1992 cited in Dhandabani, 2010). Thus it had been recognized that customers evaluate service quality by comparing the actual performance with service expectations that they held (Thakur, 2011).

\subsection{Measurement of Service Quality}

Today's knowledge intensive services businesses require reliable methods of measurement, assessment, and improvement of their performances (Spohrer \& Maglio, 2008 cited in Mosahab, et al., 2010). Gronroos (2000) cited in Mosahab, et al. (2010) referred to three dimensions of output: technical quality, service performance quality, and organization's mental picture. Also, Lehtinen and Lehtinen (1982) cited in Mosahab, et al. (20100 have referred to dimensions of physical quality, interactive quality, and organizational quality as three dimensions of service quality. Although these attempts have had a major role in division of service quality into process quality and output quality, but they lack enough details.

Extensive study on service quality conducted by researchers Parasuraman, Berry and Zeithaml (1985, 1988) cited in Kheng (2010) have proposed that service quality can be measured (Parasuraman et al., 1988, 1991, 1994 cited in Kheng, 2010) using the SERVQUAL instrument. The attributes of initial SERVQUAL model (Parasuraman et al., 1985 cited in Kheng, 2010) were: tangibles, reliability, responsiveness, competency, courtesy, assurance, credibility, security, access, and understanding. Parasuraman et al. (1988) cited in Kheng (2010) later reduced these ten dimensions into five by using a factor analysis. These five dimensions are:

1. Tangibles - Physical facilities, tools and outfit of staffs.

2. Reliability - Ability to provide service dependably and accurately as promised.

3. Responsiveness - Willingness to help customers and provide quick service.

4. Assurance - Knowledge and courteousness of employees and their ability to build trust and confidence.

5. Empathy - helpful and personalized attention provided by firm to its customers that includes access, communication \& understanding the customer.

Despite criticisms of the general applicability of SERVQUAL instrument by Cronin and Taylor (1994) cited in Thakur (2011), this instrument is a concise multiple-item scale with good reliability (Lewis \& Mitchell, 1990 cited in Thakur, 2011) and has been widely accepted as a valid instrument (Carman, 1990; Clark et al., 1992; Finn \& Lamb, 1991; Fisk et al., 1993 cited in Thakur, 2011) in the 
measurement of service quality (Thakur, 2011). The SERVQUAL instrument provides the computed disconfirmation approach whereby the difference between a customer's expectation and the actual performance is calculated (Dhandabani, 2010).

For testing the quality of banking services, many researchers have presented different models, being inspired by SERVQUAL. Avkiran (1994) cited in Mosahab, et al. (2010) has introduced a model consisting of four dimensions (personnel's contact, reliability, communication, and access to services), with seventeen components.

For this study, to analyze relationship among service quality, customer satisfaction and customer loyalty, SERVQUAL model has been used.

Another significant alternative approach is SERVPERF that measures the customer's perception of the performance of a service which provides adequate assessment for service quality (Gronroos, 1988; 1990; Cronin and Taylor, 1992; Peter et al., 1993; Brown et al., 1993; Bebko, 2000 cited in Dhandabani, 2010). Presently, increasing support is witnessed on this measurement, (Andaleeb, and Basu, 1994; Zeithaml, 1996 and Cronin et al., 2000 cited in Dhandabani, 2010).

\subsection{Customer Satisfaction}

In simple words, the evaluation of whether a product or services has met the needs and expectations of customers is satisfaction. In more comprehensive way, it can be defined as the sense of fulfillment of needs, contentment response of a customer, feelings of pleasure associated with happiness, delight, and sense of relief (Zeithaml, 2003). Numerous studies have concluded that satisfaction is an affective construct rather than a cognitive construct (Oliver, 1997; Olsen, 2002 cited in Dhandabani, 2010) that means it is derived or influenced by many other factors other than just by the customer's mental thinking. Service satisfaction has thus been assessed using items that include interest, enjoyment, surprise, anger, wise choice, and doing the right thing by Cronin et al. (2000) cited in Dhandabani (2010). Rust and Oliver (1994) cited in Dhandabani (2010) defined satisfaction as the "customer's fulfillment response" which is an evaluation as well as an emotion-based response to a service.

\subsection{Perceived Value}

From two dimensions perceived services by customers can be theoretically represented. According to Berry and Parasuraman (1991) cited in Dhandabani (2010), dimensions are- process and an outcome dimension, whereas Gronroos (1990) cited in Dhandabani (2010) termed those as- functional and technical quality. The process or functional quality refers to "how" the service is delivered and the outcome or technical quality refers to "what" customers perceive, that means the benefits of using the service. In the case of banks, how their operations are being conducted are considered as functional benefit and if the system is easy to use, safe and customers are confident on the bank are perceived as technical benefits. In the present study, the number of items used to measure the perceived value on service is four (Dhandabani, 2010).

\subsection{Customer satisfaction in Banking}

In case of the banking sector, recognized standard scales to measure the perceived quality of a bank service is not that available. Thus providing high quality service is being as an important weapon to survive and to gain and maintain competitive advantage. Inter-relation between customer satisfaction and service quality is well approved by researchers. They argued that higher service quality by banks results in higher customer satisfaction. It is also well recognized that measuring service quality is more difficult than to measure good's quality because of the unique characteristics of services: intangibility, heterogeneity, inseparability and perishability (Bateson, 1985 cited in Thakur, 2011). In this study, satisfaction has been measured considering that it is driven by service quality of the banks. It has been done through using dimensions adapted from SERVQUAL model.

\subsection{Implication of Quality and Satisfied Customers in Bank}

In case of commodity like products, quality can be measured easily by its features. But quality of service depends heavily on the quality the personnel of service provider or the provider himself. Studies on customers' switching from banks have found that they do so because they considered to be poorly serviced. Those studies also showed that nearly three-quarters of the banking customers mentioned banker courtesy as a prime consideration in choosing a bank and thus there is being increased use of service quality and professional behaviors for improved customer satisfaction and reduced customer erosion (Thakur, 2011).

Customer satisfaction is a key determining factor why customers leave or stay with a bank. Fornell (1992) cited in Thakur (2011) noted that although customer satisfaction and quality appear to be important for all firms, satisfaction is more important for loyalty in service industries like bank. Because even if the customers appear to be satisfied, they may look for other bankers if they believe they might receive better service elsewhere (Reichheld, 1996 cited in Thakur, 2011). Thus the banking organizations need to know how to keep their customers. However, keeping customers is also dependent on a number of other factors. These include a wider range of service choices, greater convenience, better prices, and enhanced income (Thakur, 2011).

Ioanna (2002 cited in Thakur, 2011) further proposed that differentiation is nearly impossible in a competitive environment like the banking industry. Banks everywhere are delivering nearly same services. Thus, bank management tends to differentiate their firm from competitors through service quality. Service quality is a 
crucial element which impact customers' satisfaction level in the banking industry. And in banking, quality is a multivariable concept, which includes differing types of convenience, reliability, services portfolio, and critically, the staff delivering the service (Storbacka et al., 1994 cited in Thakur, 2011).

Again, satisfaction is an important trait which must be taken in to account when shaping the overall loyalty of the customers towards their service providers. In banks, customers think about the level of the services and settle on about the lack of importance given to them and decide about whether to be with the bank or to switch. Minimum price with maximum usage and profit always breeds higher level of satisfaction (Jamal and Kamal, 2004 cited in Afsar, et al., 2010). When pricing is not suited to the needs of the customers, dissatisfaction usually occurs. In banking industry also, the interest rates on loans and charges on the usage of online services such as ATM machines and the processing fee is a major source of conflict between the bank and its customers. If customers think that the charges are more than it should be comparing to their needs, they switch. Competition is now fierce in banking industry as it has become too easy to open an account in any other bank that results switching cost to be very minimal. But if a customer is satisfied, the loyalty injects automatically and the customer remains with the current banker for a longer and longer period of time (Fox and Poje, 2002 cited in Afsar, et al., 2010).

\subsection{Customer's Loyalty}

Customer's loyalty has been defined in very much similar ways by most of the researchers. They have said that it is comprised of customers' attitudes and behaviors. Components of attitude are represented through repurchase intention, purchasing additional products or services from the same company, willingness to recommend the company to others, demonstration of commitment to the company by resisting to switch to another competitor (Cronin \& Taylor, 1992; Prus \& Brandt, 1995; Narayandas, 1996; Pearson 1996; Gremler \& Brown, 1996 cited in Dhandabani, 2010 and Thakur, 2011), and willingness to pay a price premium (Zeithaml, Berry, \& Parasuraman, 1996 cited in Thakur, 2011). Alternatively the behavioral aspect represents actual performing according to the loyal attitude (Feick, Lee, \& Lee, 2001 cited in Thakur, 2011). It is actually a feeling of commitment of the consumer to a product, brand, marketer, or services above and beyond that for the competitors in the market place, which results in repeat purchase (Szymigin and Carrigan, 2001 cited in Thakur, 2011). On the other hand, according to Bloemer \& Kasper (1995) cited in Mosahab, et al. (2010) loyalty is interpreted as true loyalty rather than repeat purchasing behavior, which is the actual re-buying of a brand, regardless of commitment because customers, who are not loyal, can also demonstrate repurchasing behavior. This may be due to switching costs, lack of perceived differentiation of alternatives, location constraints on choice, time or money constraints, habit or inertia which are not related to loyalty (Bitner, 1990; Ennew \& Binks, 1996 cited in Kheng, 2010).

High service quality often leads to favorable behavioral intention (Burton et al., 2003 cited in Dhandabani, 2010). But loyalty is driven by satisfaction predominantly (Rust et al., 1995 cited in Dhandabani, 2010) and therefore customer's satisfaction measurements give a better indication of future performance of service firms (Anderson and Fornell, 1999 cited in Dhandabani, 2010). In case of service arena, loyalty is often termed as "observed behaviors" (Bloemer et al., 1999 cited in Mosahab, et al., 2010). Caruana (2002) cited in Mosahab, et al. (2010) opined behavior as a full expression of loyalty to the brand and not just judgment. An operational definition often refers to the first product or service which comes to the mind of a person, while making decision for purchase. Meanwhile, Ostrowski et al. (1993) and Bloemer (1999) cited in Mosahab, et al. (2010) refer it to the first product or service that a person chooses among products and services.

\subsection{Who are Loyal Customers}

According to Srinivasan (2007) cited in Afsar, et al. (2010) there are two main categories of loyal customersloyal customers and customers with false loyalty. Loyal category consists of both satisfied and un-satisfied customers. The satisfaction is not an indispensable prerequisite for loyalty, so satisfied customers do not have to be loyal though there is a connection between the satisfied and loyal customers. True loyal customers can be unsatisfied but yet loyal due to attachment and commitment with the provider. On the other hand, customers who possess false loyalty may be satisfied customers but will always switch if they find a competitor with better quality of products and services because they lack the trust commitment and attachment with the provider's products and services. False loyalty comes from the factors due to which the customer feels hurdles and obstacles in the way, which stops him her from switching or choosing another provider. These hurdles are called switching costs. In today's technologically advanced world and due to arrival of internet, it's much more difficult to retain a customer and to gain a truly loyal customer (Afsar, et al., 2010).

\subsection{Inter-Relationship among Service Quality, Customer Satisfaction and Customer Loyalty}

Literature doesn't provide any clear message about the causal ordering of service quality and customer's satisfaction and also doesn't suggest which of these two put up a better prediction of customer loyalty (Bolton and Drew, 1991; Cronin and Taylor, 1992 cited in Dhandabani, 2010). One group of researchers argued that satisfaction is forerunner to service quality (Brady and Robertson, 2001; Dalholkar, 1995; and Winstanley, 1997 cited in Dhandabani, 2010). While another group believes that the service quality is precursor to satisfaction (Brady and Robertson, 2001, 
Bloemer et al., 2002; Newman 2001 cited in Dhandabani, 2010). A third perspective maintains that there is a nonrepetitive relationship between these two (Taylor and Cronin, 1994 cited in Dhandabani, 2010). However, the impact of service quality, customer satisfaction on customer loyalty is complex. In this study, it has been assumed that service quality affects customer's satisfaction and that impact on customer loyalty.

\subsection{Earlier Research Studies in the Field}

Despite the importance of service quality and customer satisfaction in banking, so far a few researches have been done in banking sectors of Bangladesh, but numerous researches have been accomplished outside Bangladesh. This is the main reason why this study has been accomplished. Following are the selected articles which are the base of this study and also provide an overview of earlier research works:

1. Thakur (2011) has presented that how service quality and customer satisfaction is related to customer's loyalty in Indian Banking sector's perspective. He found that customer satisfaction is significantly and positively related with customer loyalty and customer satisfaction is an important mediator between service quality and customer loyalty. In the last of the study he have discussed that banking service providers should follow right course of action to win customer satisfaction by providing better service quality in order to create loyal customer base.

2. Kheng, et al. (2010) studied on the impact of service quality on customer loyalty of the banks customers in Penang, Malaysia. They opined that a lot of competitive factors in the form of substitutes are forcing bankers to explore the importance of customer loyalty. Therefore, studies need to focus on the changing role of the banking system. They also found that improvement in service quality can enhance customer loyalty.

3. Mosahab, et al. (2010) presented a research that was conducted in a bank in Tehran, Iran. This report aimed to determine the quality of services offered by Sepah Bank, and also to study the relationship between the service quality, satisfaction and loyalty. The results of this research showed that in all aspects, customers' expectation, are higher than their perceptions of the Bank's operation, and in fact the quality of offered services is low. Besides, this research findings show that the customer satisfaction plays the role of a mediator in the effects of service quality on service loyalty.

4. Dhandabani (2010) studied on the linkage between service quality and customers loyalty in retail banking. He opined that the service quality dimensions lead to customer satisfaction and the customers' satisfaction leads to customer's loyalty. Though he revealed that there is no significant direct linkage between service quality and customer loyalty but, the service quality has a significant indirect impact on customer's loyalty especially through customer's satisfaction. His study indicated that the bank managers need to develop a systematic assessment programs to monitor service quality and customers satisfaction over time that will lead to customer satisfaction and thus to customer's loyalty.

5. Afsar, et al. (2010) worked on the determinants of customer loyalty in the banking sector of Pakistan. They argued that banking industry needs high interaction with the customers and that's why managers must understand the factors which influence the loyalty. They attempted to find the factors of customer loyalty and their relationships with the banking industry in developing countries. They examined and found that perceived quality, satisfaction, trust, switching cost and commitment are the factors which influence the loyalty of the customers.

\subsection{Significance and Value Addition to Existing Literature}

It is clearly seen that, though many research have been undertaken relating service quality, customer satisfaction and customer loyalty, basing a country or continent, there are no such direct and solo research like this study that is based on a perspective of Bangladesh. Again, none of them were on any particular city of this country with samples taken focusing only on private banks. So this study will act as a role model for interpreting the impact of service quality, customer satisfaction and customer loyalty in private banking sector of Bangladesh. With this study, banks may be able to find their loopholes and thereby take necessary steps to improve their services and to compete in better ways.

\section{Analysis and Interpretation}

Mean scores have been computed by equally weighting the mean scores of all the items. On a five-point scale, the mean scores of customers" perceived service quality of banking industries range from 3.61- 3.95 indicate that customers perceive that quality of service being offered by the service provider is quite high.

Table 1. Mean and Standard Deviation

\begin{tabular}{llll}
\hline Variable & No of items & Mean & SD \\
\hline Reliability & 6 & 3.95 & 0.7285 \\
Empathy & 4 & 3.625 & 0.86236 \\
Responsiveness & 8 & 3.718 & 0.77029 \\
Tangibles & 6 & 3.8333 & 0.714006 \\
Recovery & 5 & 3.61 & 0.80271 \\
Knowledge & 4 & 3.837 & 0.645211 \\
Perceived value & 4 & 3.65 & 0.781106 \\
Customer satisfaction & 7 & 3.757 & 0.821224 \\
Customer Loyalty & 5 & 3.79 & 0.573752 \\
\hline
\end{tabular}


From table-1 the mean score of reliability is 3.95 $(\mathrm{SD}=.7285)$ implies that the customers perceive the respective banks as reliable service providers. The mean score of empathy is 3.625 ( $\mathrm{SD}=.86236)$ meaning that the chosen bank is helpful and staffs give personalized attention to their customer. The mean score of responsiveness is 3.718 ( $\mathrm{SD}=.77029)$ implies that the banks employees are responsive to their customer. The mean score of tangibles is 3.833 ( $\mathrm{SD}=.714006$ ) which imply that the average banks have more or less attractive physical facilities, tools and outfit of staffs. Again the mean score of knowledge is $3.837(\mathrm{SD}=.645211)$. It seems that the bank's staffs are up to date with the current facts of the bank's operations and they can provide needed information to the customers if they ask for. For recovery, mean and Standard Deviation is 3.61 and 0.80271 respectively that represents that banks provide quick response on complaints and make quick correction of mistakes made. Correspondingly, Mean and standard deviation of perceived value is 3.65 and .781106 meaning that customers feel that they are getting valued services from their chosen banks.

On the other hand, customer satisfaction dimension has got the mean score of is 3.757 (SD $=.821224)$ which implies that the customers of the banking industries are satisfied with their banks. Again, Mean and standard deviation of customer loyalty is 3.79 and .573752 respectively that represents customers are on an average loyal to their bankers.

Collectively, it has been observed in the table 1 that almost all the Mean are similar and the low standard deviation represent that customers express similar type of opinion making the respective Mean more representative.

Table 2. Correlation

\begin{tabular}{ccccccccc}
\hline CS & REL & EMP & RES & TAN & REC & KNO & PV & CL \\
\hline Pearson & .55 & .49 & .49 & .52 & .54 & .41 & .50 & .47 \\
correlation & .52 & & & & & & \\
Sig. (2-tailed) & .02 & .03 & .05 & .01 & .01 & .02 & .02 & .01 \\
N & 20 & 20 & 20 & 20 & 20 & 20 & 20 & 20 \\
\hline
\end{tabular}

Table-2 shows that reliability is significantly and positively correlated with customer satisfaction $(\mathrm{r}=.55$, $\mathrm{p}<.05)$. Empathy is found to be significantly and positively correlated with customer satisfaction $(r=.49$, $\mathrm{p}<.05$ ). Referring to the table, Responsiveness is to be significantly and positively correlated with customer satisfaction $(\mathrm{r}=.49, \mathrm{p}<.05)$. The table shows that tangible is to be highly significant and positively correlated with customer satisfaction $(\mathrm{r}=.52, \mathrm{p}<.01)$. Table shows that the correlation (r) of recovery is 0.54 and the $p$-value is 0.01 . It can be concluded that recovery is highly significant and positively related to customer satisfaction in the private banking sector. It can be observed in the table that the correlation (r) of knowledge is 0.41 and the p-value is 0.02 and there is a positive correlation between knowledge and customer satisfaction in the banking sector. According to the table, the result indicates that the correlation (r) of perceived value is 0.50 and the p-value is 0.02 . Therefore, it is concluded that there is significant and a positive correlation between perceived value and customer satisfaction in the banking sector.

In the table, it can also be observed that the correlation (r) between customer satisfaction and customer loyalty is 0.47 and p-value is 0.01 . Therefore, it can be concluded that customer satisfaction is highly significant and positively related to customer loyalty in the banking sector.

\section{Findings}

From this study, it is found that the service quality of private banking sector is average. It is also found that customers are more or less satisfied with their banks. Again, scores for customer loyalty demonstrate that customers are more or less loyal to their bankers with less willingness of switching and commitment to be with the bank for longer period of time.

On the other hand, this study found that there are significantly positive correlations with the dimensions of service quality (reliability, empathy, responsiveness, tangibility, recovery, knowledge and perceived value) and customer satisfaction which means that as customers are getting quality services, they are satisfied. Again, the correlation between customer satisfaction and customer loyalty is positive and significant. Consequently, it means that customers are on an average loyal to their service provider because they are more or less satisfied.

\section{Conclusion}

Today, providing quality services to customers is no longer a matter of value addition- it is now requirement to continue and survive in the battle field of business. Service providers are recognizing this matter bitterly everyday and focusing their attention to get satisfied and loyal customers ensuring quality services consistently. Banking is one of the major service proving sectors and providing quality services is equally important for this industry. It is not a matter of surprise that customers select and choose to be with different banks evaluating quality of the services provided to them. This study was intended to find out this phenomenon in the banking industry of Khulna city in Bangladesh. And after a scientific and descriptive research, it has found that customers here are more or less satisfied with the service quality provided by their bankers as service quality is perceived to be average. Again, although customers don't have that tendency to switch from their current banks they are not yet that much active in advertising for their banks: meaning an average loyalty. So, there is enough scope for the banks to improve their service quality to attract more customers from the competitors to their own banks and that on the other hand will increase the need to improve quality to make customers more satisfied and loyal to prevent their switching to competitors. Thus, it 
can be said from this study that, providing quality service has a great impact on and intense relationship with gaining satisfied and loyal customers.

\section{References}

[1] Afsar, et al. (2010) Determinants of customer loyalty in the banking sector: The case of Pakistan. African Journal of Business Management, 4 (6), pp. 1040-1047.

[2] aims-bangladesh.com (2002) Swinging Banking: Not Very Promising. Available from: http://www.aimsbangladesh.com/special/BankingSector.pdf [accessed on August 15, 2012].

[3] Andaleeb, S.S. and Basu, A.K., (1994) Technical Complexity and Consumer Knowledge as moderators of service quality evaluation in the automobile service industry. Journal of Retailing, 70(4), pp.367-381. Cited in: Dhandabani, S. (2010) Linkage between service quality and customers loyalty in commercial banks. International Journal of Management \& Strategy, 1 (1), pp.1-22.

[4] Anderson, J.C. and Gerbeing, D.W. (1988). Structural equation Modeling in Practice: A Review and Recommended Two-Step Approach. Psychological Bulletin, 103(3), pp.411-423. Cited in: Dhandabani, S. (2010) Linkage between service quality and customers loyalty in commercial banks. International Journal of Management \& Strategy, 1 (1), pp.1-22.

[5] Angur, M.G., Natarajan, R. and Jahera, J.S. (1999) Service quality in the Banking Industry: An Assessment in a Developing Economy. International Journal of Bank Marketing, No.3, pp.116-123. Cited in: Dhandabani, S. (2010) Linkage between service quality and customers loyalty in commercial banks. International Journal of Management \& Strategy, 1 (1), pp.1-22.

[6] Avkiran, N. K. (1994) Developing an instrument to measure customer service quality in branch banking. International Journal of Bank Marketing. 12 (6), 10-18. Cited in: Mosahab, R. et al. (2010) Service Quality, Customer Satisfaction and Loyalty: A Test of Mediation. International Business Research, 3(4), pp.72-80.

[7] Bahar, H. (2009) Financial Liberalization and Reforms in Bangladesh. In: National Workshop on Strengthening the Response to the Global Financial Crisis in Asia-Pacific: The Role of Monetary, Fiscal and External Debt Policies, Session 2: Effective Monetary Policy Under the Global Financial and Economic Crisis. Thimphu: UNESCAP/UNDP/Royal Monetary Authority of Bhutan. Available from: http://www.unescap.org/pdd/calendar/Bhutan_Dec09/paper $s / 2 \_$Bahar_paper.pdf [accessed on August 15, 2012].

[8] Bebko, C.P., (2000) Service intangibility and its impact on consumer expectations of service quality. Journal of Services Marketing, 14(1), pp.9-26. Cited in: Dhandabani, S. (2010) Linkage between service quality and customers loyalty in commercial banks. International Journal of Management \& Strategy, 1 (1), pp.1-22.

[9] Berry, L.L., Shostack, G. and Upah, G. (Eds) American Marketing Association, Chicago, IL 99-107. Cited in: Kheng, L. L. (2010) The Impact of Service Quality on Customer Loyalty: A Study of Banks in Penang, Malaysia.
International Journal of Marketing Studies, 2(2), pp.57-66

[10] Bitner, M. J. (1990) Evaluating service encounters the effects of physical surroundings and employee responses. Cited in: Kheng, L. L. (2010) The Impact of Service Quality on Customer Loyalty: A Study of Banks in Penang, Malaysia. International Journal of Marketing Studies, 2(2), pp.57-66.

[11] Bloemer, J. (1999). Linking perceived service quality and service loyalty: a multi-dimensional perspective. European Journal of Marketing, 33(11, 12), 1082-1106. Cited in: Mosahab, R. et al. (2010) Service Quality, Customer Satisfaction and Loyalty: A Test of Mediation. International Business Research, 3(4), pp.72-80.

[12] Brady, M.K., and Robertson, C.J., (2001) Searching for a consensus on the antecedent role of service quality and satisfaction: an exploratory cross national study. Journal of Business Research, 51(1), pp.53-60. Cited in: Dhandabani, S. (2010) Linkage between service quality and customers loyalty in commercial banks. International Journal of Management \& Strategy, 1 (1), pp.1-22.

[13] Brown, T.J., Churchill, G., and Peter, J., (1993) Research note: improving the measurement of service quality. Journal of Retailing, 69(1), pp.127-139. Cited in: Dhandabani, S. (2010) Linkage between service quality and customers loyalty in commercial banks. International Journal of Management \& Strategy, 1 (1), pp.1-22.

[14] Caruana, A. (2002) Service loyalty. The effects of service quality and the mediating role of customer satisfaction. European Journal of Marketing, 36(7/8), 811-828. Cited in: Kheng, L. L. (2010) The Impact of Service Quality on Customer Loyalty: A Study of Banks in Penang, Malaysia. International Journal of Marketing Studies, 2(2), pp.57-66.

[15] Caruana, A. (2002). Service Loyalty: The Effects of Service Quality and the Mediating role of Customer Satisfaction. European Journal of Marketing, 36(7), 811-828. Cited in: Mosahab, R. et al. (2010) Service Quality, Customer Satisfaction and Loyalty: A Test of Mediation. International Business Research, 3(4), pp.72-80.

[16] Cronin Jr, J. J. \& Taylor, S. A. (1992). "Measuring service quality: a reexamination and Extension". Journal of Marketing, 56 (July), 55-68. Cited in: Thakur, S. (2011) Service quality, customer satisfaction and customer loyalty: a study with special reference to Indian banking industries. The Journal of Sri Krishna Research \& Educational Consortium, 1(5), pp.83-93.

[17] Cronin, J.J., and Taylor, S.A., (1992) Measuring service quality: a re-examination and extension. Journal of Marketing, 56(3), pp.55-68. Cited in: Dhandabani, S. (2010) Linkage between service quality and customers loyalty in commercial banks. International Journal of Management \& Strategy, 1 (1), pp.1-22.

[18] Cronin, J.J., Brady, M.K., and Hult, T.M., (2000) Assessing the effects of quality, value, customers satisfaction on consumer behavioral intentions in service environment. Journal of Retailing, 76(2), pp.193-216. Cited in: Dhandabani, S. (2010) Linkage between service quality and customers loyalty in commercial banks. International Journal of Management \& Strategy, 1 (1), pp.1-22. 
[19] Dalholkar, P.A., (1995) A contingency framework for predicting causality between satisfaction and service quality. Advances in consumer research, vol.22, Association for consumer research, Provo, UT., pp.101-106. Cited in: Dhandabani, S. (2010) Linkage between service quality and customers loyalty in commercial banks. International Journal of Management \& Strategy, 1 (1), pp.1-22.

[20] Danaker, P.J. (1997) Using Congest Analysis to Determine the Relative Importance of Service Attributes measured in Customer Satisfaction Surveys. Journal of Retailing, No.2, pp.235-260. Cited in: Dhandabani, S. (2010) Linkage between service quality and customers loyalty in commercial banks. International Journal of Management \& Strategy, 1 (1), pp.1-22.

[21] Dhandabani, S. (2010) Linkage between service quality and customers loyalty in commercial banks. International Journal of Management \& Strategy, 1 (1), pp.1-22.

[22] Ennew, C.T., and Binks, M.R. (1996) The impact of service quality and service characteristics on customer retention: small businesses and banks in the UK. British Journal of Management, 7, 219-230. Journal of Marketing, 52(2), 6982. Cited in: Kheng, L. L. (2010) The Impact of Service Quality on Customer Loyalty: A Study of Banks in Penang, Malaysia. International Journal of Marketing Studies, 2(2), pp.57-66.

[23] Gronroos, C (1990) Service Management and Marketing. Lexington Books, Lexington, MA. Cited in: Dhandabani, S. (2010) Linkage between service quality and customers loyalty in commercial banks. International Journal of Management \& Strategy, 1 (1), pp.1-22.

[24] Gronroos, C. (2000) Service management and marketing. John Wiley \& sons Ltd. Cited in: Mosahab, R. et al. (2010) Service Quality, Customer Satisfaction and Loyalty: A Test of Mediation. International Business Research, 3(4), pp.7280.

[25] Gronroos, C. (1988) Service Quality : the six criteria of good perceived service quality Review of Business, 9(3), pp.10-13. Cited in: Dhandabani, S. (2010) Linkage between service quality and customers loyalty in commercial banks. International Journal of Management \& Strategy, 1 (1), pp.1-22. IL 99-107. Cited in: Kheng, L. L. (2010) The Impact of Service Quality on Customer Loyalty: A Study of Banks in Penang, Malaysia. International Journal of Marketing Studies, 2(2), pp.57-66.

[26] Gupta, S.P. and Gupta, M.P. (2005) Business Statistics. $14^{\text {th }}$ ed. New Delhi: Sultan Chand \& Sons.

[27] Jamal A, Kamal N (2004) Customer satisfaction and retail banking: an assessment of some of the key antecedents of customer satisfaction in retail banking. International Journal of Bank Mark, 20(4),pp 146-160. Cited in: Afsar, et al. (2010) Determinants of customer loyalty in the banking sector: The case of Pakistan. African Journal of Business Management, 4 (6), pp. 1040-1047.

[28] Kheng, L. L. (2010) The Impact of Service Quality on Customer Loyalty: A Study of Banks in Penang, Malaysia. International Journal of Marketing Studies, 2(2), pp.57-66.

[29] Lehtinen, U., and Lehtinen, J.R. (1982) Service quality- a study of dimensions. unpublished working paper, Service Management Institute, Helsinki, 439-460. Cited in: Kheng, L. L. (2010) The Impact of Service Quality on Customer
Loyalty: A Study of Banks in Penang, Malaysia. International Journal of Marketing Studies, 2(2), pp.57-66.

[30] Levesque, T. and Mc Dougall, G.H.G. (1996) Determinants of Customer Satisfaction in Retail Banking. International Bank Marketing, No.7, pp.12-20. Cited in: Dhandabani, S. (2010) Linkage between service quality and customers loyalty in commercial banks. International Journal of Management \& Strategy, 1 (1), pp.1-22.

[31] Lewis, B.R., Orledge, J. and Mitchell, V.W. (1994) Service quality: Student's assessment of banks and building societies. International Journal of Bank Marketing, 12 (4), pp.3-12. Cited in: Dhandabani, S. (2010) Linkage between service quality and customers loyalty in commercial banks. International Journal of Management \& Strategy, 1 (1), pp.1-22.

[32] Lewis, R.C., and Booms, B.H. (1983) The marketing aspects of service quality. Emerging Perspectives in Service Marketing, in Berry, L.L., Shostack, G. and Upah, G. (Eds) American Marketing Association, Chicago,

[33] Magi, A. and Julander, C.R., (1996) Perceived service quality and customer satisfaction in a store performance framework. Journal of Retailing and Consumer Services, No.1, pp.789-209. Cited in: Dhandabani, S. (2010) Linkage between service quality and customers loyalty in commercial banks. International Journal of Management \& Strategy, 1 (1), pp.1-22.

[34] Morgan, G., Leech, N., Gloeckner, G., and Barrett, K. (2004). SPSS for Introductory Statistics. 2nd ed. New Jersey: Lawrence Erlbaum Associates, Inc. Cited in: Siddiqi, K. O. (2011) Interrelations between Service Quality Attributes, Customer Satisfaction and Customer Loyalty in the Retail Banking Sector in Bangladesh. International Journal of Business and Management [online], 6 (3), pp. 12-36. Available from: http://socialwork.academia.edu/kaziomarsiddiqi/Papers/115 7050/Interrelations_between_Service_Quality_Attributes_C ustomer_Satisfaction and Customer_Loyalty in the Retail _Banking_Sector_in_Bangladesh [accessed 16 August 2012]

[35] Mosahab, R. et al. (2010) Service Quality, Customer Satisfaction and Loyalty: A Test of Mediation. International Business Research, 3(4), pp.72-80.

[36] Newman, K., (2001) Interrogating SERVQUAL: A critical assessment of service quality measurement in a high street retail bank. The international Journal of Bank Marketing, 19(3), pp.126-139. Cited in: Dhandabani, S. (2010) Linkage between service quality and customers loyalty in commercial banks. International Journal of Management \& Strategy, 1 (1), pp.1-22.

[37] Oliver, R.L., (1997) A Behavioral Perspective on the Consumer, Mc.Graw, Hill, New York. Cited in: Dhandabani, S. (2010) Linkage between service quality and customers loyalty in commercial banks. International Journal of Management \& Strategy, 1 (1), pp.1-22.

[38] Olsen, S.O., (2002) Comparative evaluation and the relationship between quality, satisfaction and repurchase loyalty. Journal of the academy of marketing sciences, 30(3), pp.240-249. Cited in: Dhandabani, S. (2010) Linkage between service quality and customers loyalty in commercial banks. International Journal of Management \& Strategy, 1 (1), pp.1-22. 
[39] Parasuraman, A., Zeithaml, V. and Bery, C. (1985) A Conceptual Model of Service Quality and its Implications for Future Research. Journal of Marketing, Fall (49), pp.4150. Cited in: Dhandabani, S. (2010) Linkage between service quality and customers loyalty in commercial banks. International Journal of Management \& Strategy, 1 (1), pp.1-22.

[40] Parasuraman, A., Zeithaml, V. and Bery, C. (1988) SERVQUAL: A Multiple-item scale for measuring consumer perceptions of Service Quality. Journal of Retailing, Spring (64), pp.12-40. Cited in: Dhandabani, S. (2010) Linkage between service quality and customers loyalty in commercial banks. International Journal of Management \& Strategy, 1 (1), pp.1-22.

[41] Parasuraman, A., Zeithaml, V.A. and Berry, L.L. (1988) SERVQUAL: a multiple-item scale for measuring consumer perceptions of service quality. Journal of Retailing, 64(1), Spring. Cited in: Kheng, L. L. (2010) The Impact of Service Quality on Customer Loyalty: A Study of Banks in Penang, Malaysia. International Journal of Marketing Studies, 2(2), pp.57-66.

[42] Peeler, G. H. (1996). Selling in the quality era. Blackwell Business, USA. Cited in: Mosahab, R. et al. (2010) Service Quality, Customer Satisfaction and Loyalty: A Test of Mediation. International Business Research, 3(4), pp.72-80.

[43] Peter, J., Churhill, G. and Prown, T., (1993) Contain in the uses of difference scores in consumer research. Journal of Consumer Research, 19(4), pp.655-662. Cited in: Dhandabani, S. (2010) Linkage between service quality and customers loyalty in commercial banks. International Journal of Management \& Strategy, 1 (1), pp.1-22.

[44] Rashid, M. (2010) Banking sector challenges in Bangladesh. In: The Daily Star, on Sunday, September 19, 2010. Available http://www.thedailystar.net/newDesign/newsdetails.php?nid=154934 [accessed on August 15, 2012].

[45] Rust, R.T., and Oliver, R.L., (1994) Service Quality: insights and managerial Implications from the frontier, Sage Publications, Thousand Oaks, CA., pp.72-94. Cited in: Dhandabani, S. (2010) Linkage between service quality and customers loyalty in commercial banks. International Journal of Management \& Strategy, 1 (1), pp.1-22

[46] Spohrer, J. \& Maglio, P. (2008) The emergence of service science: Toward systematic service innovations to accelerate co-creation of value. Production and Operations Management, 17(3), 238-246. Cited in: Mosahab, R. et al. (2010) Service Quality, Customer Satisfaction and Loyalty:
A Test of Mediation. International Business Research, 3(4), pp.72-80.

[47] Srinivasan SS, Anderson R, Ponnavolu K (2007) Customer loyalty in e-commerce: an exploration of its antecedents and consequences. Journal of Retailing, 78(1), pp. 41-50. Cited in: Afsar, et al. (2010) Determinants of customer loyalty in the banking sector: The case of Pakistan. African Journal of Business Management, 4 (6), pp. 1040-1047.

[48] Szymigin, I., and Caruigan, M., (2001) Wherefore customers loyalty? Journal of Financial Services Marketing, 6(2), pp.6-8. Cited in: Dhandabani, S. (2010) Linkage between service quality and customers loyalty in commercial banks. International Journal of Management \& Strategy, 1 (1), pp.1-22.

[49] Takeuchi, H., and Quelch, J.A., (1983) Quality is more than making a good product. Harvard Business Review, JulyAugust, pp.139-145. Cited in: Dhandabani, S. (2010) Linkage between service quality and customers loyalty in commercial banks. International Journal of Management \& Strategy, 1 (1), pp.1-22.

[50] Thakur, S. (2011) Service quality, customer satisfaction and customer loyalty: a study with special reference to Indian banking industries. The Journal of Sri Krishna Research \& Educational Consortium, 1(5), pp.83-93.

[51] Winstanley, M., (1997) What dries customers satisfaction in commercial banking. Commercial Leading Review, 12(3), pp.36-42. Cited in: Dhandabani, S. (2010) Linkage between service quality and customers loyalty in commercial banks. International Journal of Management \& Strategy, 1 (1), pp.1-22.

[52] Zeithaml, V.A., (1988) Consumer perceptions of price, quality and value: a means - end model and synthesis of evidence. Journal of Marketing, 52 (July), pp.2-22. Cited in: Dhandabani, S. (2010) Linkage between service quality and customers loyalty in commercial banks. International Journal of Management \& Strategy, 1 (1), pp.1-22.

[53] Zeithaml, V.A., (2003) Services Marketing. $4^{\text {th }}$ ed. New Delhi: Tata McGraw-Hill Publishing Company Limited.

[54] Fornell, C and Larcker, D.M. (1981), "Evaluating Structural equation models with unobservable variables and measurement error", Journal of Marketing Research, 18(1), pp.39-50. Cited in: Thakur, S. (2011) Service quality, customer satisfaction and customer loyalty: a study with special reference to Indian banking industries. The Journal of Sri Krishna Research \& Educational Consortium, 1(5), pp.83-93. 